\title{
THE SHIFTING PARADIGMS IN THE IMPLEMENTATION OF CLT IN SOUTHEAST ASIA COUNTRIES
}

\author{
Martin Kustati \\ Dosen Fakultas Tarbiyah dan Keguruan IAIN Imam Bonjol Padang \\ e-mail: martinkustati@yahoo.com
}

\begin{abstract}
Foreign languages teachers in South East Asia have recently been encouraged to adopt an approach known as Communicative Language Teaching (CLT). This approach advocates the development of communicative competence as a main goal through the extensive use of the target language as a mean of communication during the classroom sessions. Since the concept of CLT is taken from the West, it might be illsuited to EFL contexts because of misunderstandings surrounding its theory and practice among EFL teachers. The objective of this paper is to determine the implementation of CLT approach in EFL teaching in Southeast Asia which is commonly reported by English teachers and researchers literally. The findings of the study provide pedagogical implication for EFL classroom practices.
\end{abstract}

Key words: implementation, communicative language teaching approach, Southeast Asia

\begin{abstract}
Abstrak: guru bahasa Inggris di Asia Tenggara telah mengadopsi sebuah pendekatan yang disebut dengan pendekatan komunikatif. Pendekatan ini bertujuan untuk meningkatkan kompetensi komunikatif sebagi tujuan utama melalui penggunaan bahasa target yang sesuai dengan konteks pembelajaran bahasa Inggris sebagai bahasa Asing di dalam kelas. Karena konsep pembelajaran bahasa yang komunikatif diadopsi dari Barat, kemungkinan pendekatan ini tidak sepenuhnya sesuai dengan konteks bahasa asing. Tujuan dari artikel ini adalah untuk mengetahui penerapan pengajaran komunikatif di Asia Tenggara yang telah dilaporkan oleh para pendidik dan peneliti. Temuan hasil penelitian ini akan memberikan implikasi pedagogis terhadap pengajaran bahasa inggris sebagai bahasa asing.
\end{abstract}

Kata Kunci: penerapan, pengajaran bahasa Inggris komunikatif, Asia Tenggara

\section{INTRODUCTION}

This paper is derived from a small part of my literature review in the Ph.D thesis, which focuses on the implementation of communicative language teaching approach. English plays an essential role in many aspects of life, such as academic, diplomatic and economic pursuits in Southeast Asia and beyond. However, Southeast Asians who have learned English as a foreign language (EFL) present a different picture compared to other people who have also learned English as a second language (ESL).

Current trend in the teaching of EFL in Southeast Asia has given emphasis on communicative language teaching (CLT) as one of the innovative methods within the last quarter of a century (Jarvis, 2004). As an approach in the teaching of second and foreign languages, it highlights the role of interaction as both the means and ultimate goal of learning a language. It is also referred to as communicative approach to the teaching of foreign languages. Responding to the advent of CLT, English teachers roles have changed. They were no longer simply the drill leader but were also charged with providing students with opportunities for communication using the target language to interpret and express real-life message (Lee, 2003). This approach has transformed the way language teaching is conducted.

Based on the report from www. retireasia.com, the standard of English language teaching at the primary and secondary school level in countries like Indonesia, Thailand and 
Laos is still generally low. Teachers in government schools who are underpaid teach with very limited resources. They have so far only engaged in rudimentary training and lack of competent in English subject matter. Textbooks are often written in the native language. When translated into English, they contain many spelling and grammatical errors and they go generally unnoticed by the nonEnglish speaking readers. Errors, finally, are passed down to the students.

Given the above realities, the biggest challenge facing some countries in Southeast Asia is the absence or minimal exposure to practical use of English. Students' engagement in real-life communication activities and all kinds of environmental supports are crucial to produce learners' oral competent. Kumaravadivelu (1993) reports that even teachers who are committed to Communicative Language Teaching can fail to create opportunities for genuine interaction in the language classroom. It is caused by a number of factors, such as teachers' inadequate command of English, poorly designed teaching materials and and large classroom size and power structure of typical classroom in some Southeast Asian school (Jarvis 2004; Kwangsawad 2007).

The most relevant issue in this paper is the implementation of Communicative Language Teaching in EFL classroom in Indonesia, Vietnam, Thailand, Laos, Cambodia, and Myanmar (Burma), while it is an ESL in other Southeast Asian countries, such as... Therefore, it is still necessary to identify the CLT approach employed by English teachers in teaching EFL in these six Southeast Asian countries. This paper studies the implementation of communicative language teaching (CLT) in the teaching of EFL through perspectives of literature and research. At the same time, problems faced by the teachers in implementing this approach are also described.

\section{THE IMPLEMENTATION OF COMMUNI- CATIVE LANGUAGE TEACHING (CLT) APPROACH IN EFL TEACHING IN SOUTHEAST ASIA: SHIFTING PARA- DIGMS}

Developments in the implementation of CLT approach in the teaching English in Southeast Asian countries are presented based on reviews of published and unpublished documents. The efforts to analyze this issue relatively a new phenomenon. One of the examples of these efforts has been introduced through what Eisner (1985) called structural corroboration, a process in which information is gathered from different resources and is cumulatively linked to form a clearer picture of the situation. Kam and Wong (2003) also wrote on this issue and described the status of English in each of the 15 countries in East Asia, including the position of ELT in EFL countries in Southeast Asia today.

Looking at how ideas are transmitted cross-culturally, it is observed that there is now much scepticism from outsiders as to whether the kind of strategy in CLT works in Southeast Asian classrooms. Kam and Wong (2003) state that some ethnographic studies on ELT classrooms found that genuine interaction (real life communication) are difficult to establish. It implies that there has been limited understanding of the cultural norms of classroom to which CLT approach is transferred.

In EFL settings in Southeast Asia, English is still rarely spoken outside classrooms although it is a compulsory subject. This is so because the temptation for students and teachers to use native language is too strong to resist. They would rather use English during communication with English native speakers, travelling to English speaking countries, and attending English workshops, trainings, seminars and speech contests. Creating authentic English spoken situations seems to be the biggest challenge for EFL teachers in those countries. 


\section{CAMBODIA}

English began to be taught as a foreign language in Cambodia in 1989 (Vira, 2002). EFL is taught in primary and secondary schools' curriculum and it has become a compulsory subject since September 1990. English has become the most popular choice among Cambodian schools. Vira (2002) added that there are three development stages of ELT in Cambodia. First, the Ministry of Education set up an English curriculum committee in 1989 to help design an English syllabus for lower secondary level. As a result Cambodian English course was established and was intended to be used in Grade 7. However because of the lack of international support, the development of an English syllabus was suspended.

The second development stage was in 1995. The government formed another committee. The first outcome was the teaching syllabus in English for Grades 7, 8, and 9. Having tried this syllabus however, it seemed too complicated to implement. Finally, the latest version was developed and officially, there are now two foreign languages to be learned -English and French.

In addition, Pou (1996) mentioned that the Ministry of Education, Youth and Sports have insufficient number of qualified teachers, facilities, and teaching resources to effectively prescribe English in the curriculum. According to Chamnan and Cornish (1997), there were also fewer English trained teachers $(n=238)$ as compared to other foreign languages such as French $(n=1,200)$ for the 468 secondary schools. This data proved that there is still a need to increase the number of English-trained instructors. Vira (2003) added that from year to year, a number of aid projects have attempted to enable English to be implemented with a high or at least acceptable quality.

In the field of English language teaching, there have been considerably many reconstructive efforts taken; among others, the mammoth tasks of training teachers, designing and formulating the English language curriculum for secondary schools up to universities, and producing teaching materials. In teaching methodology, the traditional Grammar-Translation Methods reportedly prevailed, which involve memorisationreproduction and the learning of structural English (Suon, 1990). He added that the method commonly used in Cambodia is teachercentered and the only language used in the classroom is teacher/text-controlled and structured.

\section{INDONESIA}

English has been a compulsory subject in Indonesian education since the 1950s, when the government mandated foreign language to be included in school curriculum nationwide (Nur 2003). This policy, which stems from the belief that English has become a lingua franca, aims to make students globally competitive; thus, students must be able to acquire competency in the language. English instruction in Indonesian classroom should cover the the four skills: speaking, listening, reading and writing.

One of the attempts of educational policymakers to improve the quality of ELT is to adopt the communicative language teaching (CLT) approach into the Indonesian school curriculum in 1984 from elementary up to university levels (Curriculum 1984, Minister of National Education Regulation No. 060/U/1993; Yasin; 2001; Suyanto 2001; Nur 2003). This policy is expected to yield more effective results on the English proficiency of students as compared to other approaches. This implies that traditional methods have been unsuccessful to produce Indonesian students who are competent in both oral and written English 1. Unlike other traditional methods, CLT has been emphasized on the "communicative competence" of students (Hymes 1972; Canale and Swain (1980); Littlewood 1981; Savignon 1987; Celce-Murcia, Dornyei Turrel \& Thurrell 1995; Richards \& Rodgers 2001; Brown 2001; Nunan 1989).

However, in reality, the Indonesian curriculum is facing difficulties in implementing CLT's principles (UNESCO: Statistical Year 
1998). The 1994 English curriculum was overloaded with insignificant subjects. Every local area or district was allowed to add subjects based on their localities such as subjects on local languages, arts and skills. Furthermore, the curriculum was seen to be focusing on a teacher-centered approach which causes students to be passive learners.

Mustafha (2001) found that the implementation of CLT in Indonesian schools has not always met with success for several factors.. One of which is the teacher's degree of confidence in using the target language before their own students. In a situation where a teacher fails to show confidence and enthusiasm, it is difficult to expect students to communicate in English. The second reason are time constraints that reduce teachers' opportunity to provide spaces for students to communicate in the classroom. The large class size is also a big issue in Indonesian schools. Commonly packed with about thirty to forty students in one classroom, and coupled with a crowded curriculum, many teachers cannot afford to provide well-designed, meaningful exercises for students to use what is being learned on one-toone basis. Another reason is the type and focus of the exam. As presently practiced, the nationally-administered test (UN) is commonly dominated by questions which are form-focused and presented in a multiple-choice format, which does not allow divergent thinking.

According to Mustafha (2001), other hindrances in the implementation of Communicative Language Teaching approach include the following: absence of good, authentic learning materials, teachers' tendency to rely on non-communicatively-engaging learning tasks (such as those grammar-based worksheet), and the absence of visible social uses of the language outside the classroom confine. All of this can stand in the way of the development of a sense of relevance in learning English, which can, in turns, create further psychological distance on the part of learners.

Hamied (1997) also adds that there is a lack of qualified English teachers and inadequate teacher-training program to train English teachers inside and outside of urban centers. Since the research cited in Hamied (1997) was conducted in Java (considered as the educational center of the country), it can be assumed that the situation in rural areas outside Java may be much worse. Setiono, 1999b; Alwasilah 1997; Beh (1997; Dardjowidjojo 2000; Jayadi 2000; Musthafa 2001; Nur 2003; Zainil 2005 also argue that English teachers have failed to adopt the communicative paradigm of modern English teaching methodology. These scholars suggest that this situation is brought about by declining levels of teachers' attitudes and students' difficulties in purchasing the required texts (Beh 1997).

Lewis (1996) finds that a majority of English students are silent during English class. They only occasionally participate in the pronunciation drills or answer comprehension questions on the reading or grammar exercises. Learning period is usually spent copying from the blackboard and translating texts and vocabulary words from English to Indonesian. In English classes, Indonesian students report that most of their learning solely comes from studying the authorized English textbooks. Although there is a new curriculum (KTSP 2006) and textbooks embracing communicative language teaching, with emphasis on communicative proficiency, findings, teachers still favor the traditional model of grammar translation and direct teaching methods (Lewis 1996)

Beh (1997;2004) and Exley (2005) point out that students in rural areas have a low level of English proficiency and poor motivation to learn as compared to the students in urban areas. This is because there are fewer learning/teaching resources, under-qualified teachers, and inadequate number of teachers in rural areas available (country report, 2004). Rural high schools are not well supported by their supervisors and district officials. The teachers even claim that there are other problems such as budget constraints to carry out their jobs and geographic barriers. These cause considerable hardships for teachers in implementing the CLT in rural schools. Some of these problems are attributed to the students' 
very low English proficiency level. In addition, salaries are not attractive enough to recruit new teachers to work in urban and rural areas.

Although teachers' lack competent has been attributed to be the main hindrance in English teaching methodology (from grammar centered methodology to communicative language teaching approach), Dardjowijojo (1996) and Kam and Wong (2003) put the blame on the lack of students motivation, poor attitude of students to learning English, and a shortage of teachers adequately competent in the language.

\section{VIETNAM}

English syllabus developed in Vietnam attempted to move towards CLT. Kam and Waong (2003) mentioned that Vietnam has made the CLT as a target "to learn a foreign language in order to use it for communicative purposes, as is now the declared aim of the Vietnamese education authorities, the learners need to develop not only linguistic competence but also communicative and social competence in the language" (Tran Xuan Thao, 1991, 190). This approach has been considered by the government of Vietnam to be the current method of teaching English in the schools.

Although Vietnamese government has issued a policy that CLT is the appropriate method to be implemented in all grades level, Nguyen and Sloper (1995), Pham (1999); Van (2008) mention:

Vietnamese students' language learning styles, like their Chinese counterparts' (Rao, 1996), are characterized by two main features: meticulous attention to linguistic and stylistic details rather than communicative skills, and the use of translation as the indispensible learning strategy.

This is clearly proved that a common Vietnamese used in the classroom is heavily based on Grammar-Translation Methods where the teachers explain the lessons, students attend the class, take notes, but few deliberately pose questions, volunteer to answer questions, or take part in discussion.

Van (2008) states that the implementation of CLT faces three challenges in Vietnamese schools: the Vietnamese traditional culture of learning; teachers' limited professional development and the constraints of the curriculum. First, learning culture in Vietnam has been for very long deeply and overwhelmingly influenced by Chinese; Confucian ideology where...." there are correct ways of studying texts, just as there are correct text to study and there appropriate questions to ask, with clearly appropriate- and knownanswer to such questions" (Ballard \& Clanchy, 1991, p.24). From this ideology, it can be inferred that the Vietnamese students need to learn what their teachers transmit to them, and the teachers are considered to be sources of knowledge and wisdom. It is rare for the students to obtain the encouragement for critical thinking and analysis and this culture remains to the present (Tran, 1998). This learning culture in turns shape classroom practices, in which by teachers-centered is still a common place in the classroom.

Second, the limitation of teachers' professional development contributes a great influence on the success of CLT implementation. There are limited workshops, trainings, and seminars on CLT approach. Although some Vietnamese teachers have been trained about CLT, big class size is still problematic.. In addition, classroom cultures and seating arrangement are factors that discourage the implementation of CLT in the Vietnamese education. .

Another shortcoming that impedes the Vietnamese teachers to implement CLT is the heavy workload curriculum (Van, 2008). There are a lot of teaching materials to be run in limited time. Regarding the implementation of CLT approach, it is mostly impossible because it involves many communicative activities (pair work, role play, discussion, students' presentation, etc) which take time. It can be summed up that although the teachers want to implement CLT, the time and curriculum do not allow them. 
From the explanation above, Van (2008) suggests some solutions to the implementation of CLT issues. Firstly, the Vietnamese English teachers should improve the students' motivation. Therefore, the teachers should play their roles as facilitators until the students feel comfortable with the new method. Then, the teachers should also consider different ways of students' learning because of various characteristic of human behaviour. Thirdly, referring to the pressure of time due to heavy load curriculum, the Ministry of Education and Training should consider carefully the necessity of CLT implementation and upgrade the quality of teaching and learning. The ministry can welcome English staffs for modification, to suit the aim of CLT approach.

\section{THAILAND}

Ministry of Education (2001) mentions that English as a Foreign Language (EFL) is a compulsory subject for all grade levels and other foreign languages are elective. ,. The overall aims of foreign languages (mainly English) in Thailand are "to develop students' basic practical communication abilities, understand of language and culture, and foster a positive attitude toward communication through foreign languages (Kwangsawad, 2007). In consideration of these objectives, there are several issues that the Ministry of Education points out to improve English education and teaches. First, administrators, teachers, and teacher-educators need to approach English teaching from different perspectives that incorporate more opportunities for authentic language use during communication, goaloriented activities in smaller classrooms. Furthermore, Bilingual programs are conducted at the levels of primary, secondary, and diploma in schools. Thus Thai EFL teachers have to employ communicative language teaching (CLT) approach and content-based approach.

As Thanachanan (1983cited in Jantrasakul 2004) proved that English teaching in primary and secondary schools predominantly emphasizes cognitive learning of grammatical rules with meaningless oral drill skills. Learning by memorizing (audiolingual method) is highly favoured in Thai context.
Knee (1999) offered an account of his EFL teaching experience in Thailand, in which he failed to understand local learning culture. He believed that local cultures significantly influence language learning.

Historically, CLT was first introduced to secondary school teachers by Ministry of Education in 1984. To make CLT workable, the Ministry of Education trained EFL teachers through various means such as PISET (Project for Improving Secondary English Teachers), Key Personnel Project. However, having been trained CLT and then implemented CLT, EFL trained-teachers realized that it was difficult to turn theory in to practice. Bilash \& Kwangsawad (2004 cited in Kwangsawad (2007) conducted action research in Thai classroom and recruited four participant teachers. They found that to help EFL teachers successful to adopt CLT in their classroom, teachers have to understand the concept of CLT, require a number of key supports, and prepare materials for interactive activities.

Kwangsawad (2007) found that four reasons make CLT unsuccessful in Thailand: First, First, the EFL teachers in Thailand have heavy workloads. The teachers mostly teach 25 to 28 hours a week. They were also responsible for academic affairs, budget and personnel, student affairs and service affairs. It certainly will prevent them from devoting much time to class preparation and from sharing ideas with their colleagues.

Second, the interference of first language (L1) was remarkably strong. The English teachers did not use target language (L2) because they were afraid of making mistakes. They believe that teachers should speak perfect English. This leads to students' passivity because they rarely hear English spoken in their classroom.

Third, the use of traditional methods in Thailand persists. In fact, if English teachers implement CLT approach, classes were lack of student-to student interaction, and no movement out of desk or pair work during theclasses. A majority of untrained teachers were unfamiliar with the cassette player and it took so slow that the preparation to listen took up time that the students needed for practice. 
The last reason is the situation of CLT classes where the teachers did not allow much time for the students to practice their English. The teachers still play the traditional role (teacher-centered) where their students only called upon primarily to provide brief and factual responses. They were also unclear how to design activity during presenting the materials in the class. In addition, they encountered difficulties in selecting texts, materials and activities that would the unit lessons.

Based on the situation of ELT and CLT implementation in Thailand above, it can be summed up that it is still difficult for Thailand teachers who themselves have learnt English from traditional methods shift their teaching to a communicative approach and the use of language as a tool for learning content. They felt they did not have enough time to prepare their lesson. They would want to retain the more familiar grammar translation and drill and skill methods that become more comfortable to be implemented.

\section{LAOS}

More recently, English has become the most popular foreign language in schools and universities in Laos since 1990s. The emphasis of ELT is on reading to help students keep abreast of the developments in science and technology. As Laos began to move from a centrally-planned economy to a market economy, English has increased its popularity as a subject of study. This sudden change in direction created predictable problems such as shortage of English teachers, lack of instructional materials in English aside from those imported from overseas and no properly designed English curriculum to meet the actual needs of the system. To meet the teachers' shortage, local teachers trained to teach Russian and French were deployed and re-trained to teach English.

The government of Laos issued a policy to implement Communicative Language Teaching (CLT) approach into school curriculum, from primary up to university levels. The English teachers are expected to adopt the
CLT, but, according to Kam (2003), when the cultural variable of Lao situation taken into account, CLT cannot be fully implemented in the classroom. The objective of ELT in Laos also influences the successful of CLT implementation. The teachers mainly enable high schools students to read books and to keep up in the development of information and technology.

\section{MYANMAR}

Historically, the importance of English is less compared to that of the national language, particularly the status of English in the schools and higher education in Myanmar. Kam and Wong (2003) mentioned that from 1958 and especially from 1965 when all schools throughout the country were nationalised, English was offered in the fifth grade. As a result, the standard of English in the schools gradually declined (Allott, 1985, 141-142).

The government has started to pay attention on the development of English since 1970. A series of seminars on ELT was held between 1978 and 1982. English became a medium instruction for most subject in Myanmar since the New Education of 1981 (Myo Mint, 1999). Myo Mint stated that all this was supported by a strong desire among today's younger generation to master the language.

Kyu (1993) mentioned that the introduction of English as medium of instruction created a tremendous amount of pressure and anxiety for staff members and school teachers who themselves had gone through an education system in which English was not medium of instruction. According to Myo Mint (1999) and Poe Poe (2003), English was only given enough attention by the LongTerm Thirty Year Education Plan (initiated in the 2001-2002 fiscal), which envisions the creation of an educational system that can generate a learning society capable of facing the knowledge age.

\section{DISCUSSION}

The issues of English language teaching in six Southeast Asian countries faced a 
number of dilemmas:: supply and existence of qualified English teachers, students' readiness to use English, time constraints, classroom sizes, structured exam, unconducive and unsupportive environment of using English outside classroom, budget constraints, availability of teaching materials, teaching methodology and the like.

These issues lead us to a conclusion that the distinction between ESL and EFL settings should be taken into account upon implementing a particular teaching methods. In countries where English is learnt as a second language, English is used quite extensively outside classroom. The dominant environment is English and the non-native speakers are able to learn the language of the majority of the population, as in the case of non-native speakers of English learn in Singapore, Malaysian, and Philippines. They have used English in expressing all of their ides and feelings, except probably during intimate conversations with close friends and family. In an ESL context, all of four language skills (listening, speaking, reading and writing) are be used, and the English language are employed in a variety of registers ranging from the very informal to the highly formal.

Unfortunately, this is not the case in EFL setting where the non-native English speakers study English in an environment where the dominant population speaks a different language. They are studying EFL, as in the case of Indonesian students learning English in their country. In this situation, English is being studied as one of many foreign languages to serve a little communicative function for the students once they finish their formal learning in the classroom. In Indonesia, communicative use is limited and may focus only on literature and the so called high culture. Translation may also be stressed. The use of English for any purpose outside of classroom is minimal and short of duration.

According to Kam and Wong (2003), the EFL learners have limited contacts with native speakers on the daily basis, whether as visitors to their own country. It proves that for many even such temporary usage might never occur. Thus in EFL situation, very few people other than those in the teaching profession use
English on a regular and long-term basis. The English teachers tend to use their first language instead of English in teaching.

Dornyei (2001) suggests five helpful strategies to implement CLT successfully in the classroom. These strategies are helpful because they allow students to gain self confidence to use English in real-life communication: (1) teachers need to foster the view that competence is not a static condition but an ongoing process; t growth is gradual but sure; (2) teachers need to provide regular experiences of using in the classroom of using English; (3) teachers need to give opportunities to the learners to contribute meaningfully. When students feel that they can contribute, they will feel more interested; (4) teachers need to praise the learners for their contribution and their progress. An occasional word of encouragement will elevate their spirits and level of motivation. In this context, Patil (2008) related to a custom prevalent among the citizens of Solomon Islands. Patil (2008) also says that when these people want to cut a tree, they do not use any axe or saw to cut it; they gather around it and spelt curses and swear words. After a few days, the tree withers away and collapses. I think this custom has a lot to teach us; and (5) they need to make the classroom climate less stressful. Learning gains momentum when the classroom situation is relaxed, friendly and homely.

\section{CONCLUSION}

In these several Southeast Asian countries, English has been compulsory in all school levels even though it is a foreign language rather than the second language. Kam and Wong (2003) suggested this policy aims at preparing citizens of these countries to acquire adequate English competent. To do this, these countries have made several efforts in observing English teaching methodology from western contexts. These countries then believe that CLT would be more appropriate as one of the language teaching methods.

However, CLT approach in Southeast East Asian countries is rather unsuccessful. This is because the confusion surrounding its theory and practice among EFL teachers. In addition, dramatic shifts from traditional method to CLT 
has overwhelmed for most Indonesian, Vietnamese, Laos, Thai, Myanmar, and Cambodian teachers, especially for those in small rural schools, in which English teachers have been found to be unqualified. Unwillingness to change in teaching methodology makes 'traditional teaching method' persists in many English classrooms in those countries.

Even though the applicability of CLT seems gloomy in those countries, this article suggests that CLT may finds its ground in those six Southeast Asian countries, if CLT is made more culturally wise. EFL classrooms, in which CLT is used, need to be flexible and reflective to suit the local culture and the EFL context. Teachers also need to improve students' motivation to engage with the current method, facilitate the English teacher with sufficient of knowledge on CLT, and review the overloaded curriculums (as in the case of Thailand, Vietnam, etc).

\section{REFERENCES}

Alwasilah, A.C, 1997. December 13. Elements for minor languages. The Jakarta Post.

Abdul-Hamied, Abdul. (2001). English language education in Indonesia. Paper presented at East-West Center and Ohana Foundation Workshop, East West Center, Honolulu, Hawaii, 16-17 February.

Allott, Anna J. 1985. Language policy and language planning in Burma. In Language Policy, Language Planning and Sociolinguistics in South East Asia, edited by David Bradley. Pacific Linguistics, Series A, No. 67.

Bax, S, 2003. The end of CLT: a context approach to language teaching. ELT Journal 57/3: 278 -87.

Beale, J., 2002. Is communicative teaching a thing of the past ?. Babel 37 (1), 1216. Available from: Error! Hyperlink reference not valid.. [May 12 2009].

Belchamber, R., 2007. The Advantage of Communicative Language Teaching.
Available from: http://itesj.org.

[Pebruary 25 $\left.5^{\text {th }} 2008\right]$.

Beh, Y., 1997. Current research in South East Asia. RELC Journal, 28 (1), 175-179.

Brown, H. D., 2001. Teaching by Principles: An Interactive Approach to Language Pedagogy. New York: Longman.

Canale, M., \& Swain, M. (1980). Theoretical based of communicative approaches to second language teaching and testing. Applied Linguistics, 1 (2): 11-47.

Chamnan, Pit and Cornish, Audrey. 1997. Language and development in Cambodia. In Language and Development: Teachers in a Changing World, edited by Brian Kenny and William Savage. London: Longman.

Celce-Murcia, M., Dornyei, Z., and Turrell, S., 1995. Communicative Competence: a Pedagogical Motivated Model with Content Specifications. Issues in Applied Linguistics 6 (2): 5-35.

Dardjowidjojo, S. 1996a. English Policies and Their Classroom Impact in Some ASEAN/Asian Countries. Paper presented at the RELC International Seminar, Singapore, 22-24 April.

Dardjowidjojo, S, 1996b. The Role of English in Indonesia: A dilemma. Paper presented at the TEFLIN Seminar, Surabaya, Indonesia, 7-10 October.

Dardjowidjojo, S, 2000. English teaching in Indonesia. EA Journal 18 (1), 22-30.

Eisner,E.W. 1985. The Educational Imigination. $2^{\text {nd }}$ ed. New York: Macmillan.

Hamied, F.A., 1997. Program surveys in Indonesian Scools: Towards EFL curriculum implementation for tomorrow. In Language Classrooms of Tomorrow: Issues and Responses, edited by George Jacobs. Singapore: SEAMEO Regional Language Centre.

$\mathrm{Hu}$, G., 2002. Potential cultural resistance to pedagogical imports: the case of communicative language teaching in 
China. Language, Culture and Curriculum. [Accessed October 20, 2006].

Hymes, D., 1972. On Communicative Competence. Edited by J.P. Pride and J. Holmes (ed.), Sociolinguistics. Harmondsworth, UK: Penguin.

Huda, Nuril. 1993. Reorientation in the objectives of ELT in the secondary schools in Indonesia. In Language and Content, edited by N. Bird, J. Harris and $\mathrm{M}$. Ingham. Hongkong: Institute of Language in Educational Journal, 8, $10-24$

Jarvis, H. \& Atsilarat, S., 2004. Shifting paradigms: from a communicative to a context-based approach. Asian EFL Journal. December 2004. [January 14 2008].

Jayadi, L., 2000. Constraints and Resources for applying communicative approaches in Indonesia. EA Journals, 18 (1): 31 40.

Liao, X., 2004. The need for communicative language teaching in China. ELT Journal 58/3:27.

Littlewood, W., 1981. Communicative Language Teaching: an Introduction. Cambridge: Cambridge University Press.

Lewis, R., 1996. Indonesian Students' Learning Style. EA Journal, 14 (2): 27-32.

Kam, H.W, Wong R.Y.L. 2003. English Language Teaching in East Asia Today: Changing Policies and Practices. Singapore: Time Academic Press.

Kachru, Braj B. 1996. English as an Asian Language. In English is an Asian Language, edited by Mria Lourdes S. Bautista. Australia: The Macquaire Library Ltd.

Kumaravadivelu, B. 1993. Maximizing learner potential in the communicative classroom. ELT Journal, 47 (1), 12-21.
Kwangsawad, T. 2007. Bridging the gap between CLT and CBI theories and practices in Thai small rural schools. The $1^{\text {st }}$ International Conferences on Educational Reform 2001. Mahasarakham Universoty, Thailand. Unpublished article

Mustafha, B., 2001. Communicative language teaching in Indonesia: issues of theoretical assumptions and challenges in the classroom. Journal of Southeast Asian Education 2 (2): 1-9.

Myo M. 1999. The Teaching of English in Myanmar. Unpublished Conference Paper.

Myo,M \& Poe, P. 2003. English Language Teaching in Myanmar: Current Status. in Ho Wah Kam and Ruth Y.L. Wong (eds.), English language Teaching in East Asia Today: Changing Policies and Practices. (Singapore: Eastern University Press).

Nunan, D., 1989. Designing Task for Communicative Classroom. Cambridge: Cambridge University Press

Nur, C., 2003. English Language Teaching in Indonesia: Changing Policies and Practices: In Kam, H.W., and Wong, R (eds.). English Language Teaching in East Asia Today: Changing Policies and Practices. Singapore: Times Academic Press.

Patil, Z.N. 2008. Rethinking the Objectives of Teaching English in Asia. Asian EFL Journal. Vol 1 (4).

Pou, D. 1996. Seminar of ELT in Cambodia. Department of English and Education, Rupp, pp.9-12.

Richards, J.C., \& Rodgers, T.S. 2001. Approaches and Methods in Language Teaching $\left(2^{\text {nd }} \quad e d.\right)$ Cambridge University Press.

Setiono, 1999b. August 7. Challenges in Teaching English Composition. Jakarta Post. 
Suon, Champon. (1990) English language Curriculum for secondary schools. Reportof the Australian of Australian Quaker Service for Ministry of Education, State of Cambodian.

Suyanto, K.K.E., 2001. Kurikulum Bahasa. http://209.85.173.104/search . [April $\left.14^{\text {th }} 2008\right]$.

Teaching English in SE Asia. Retrieved at http://www.retire-asia.com/teaching English.shtml. October 27, 2009.

The Indonesian Country Report, 2004. http://memory.loc.gov/frd/cs/profiles/i ndonesia.pdf. [Accessed June 29 2009].

Tan, M., 2005. CLT - Beliefs and Practices. Journal of Language and Learning3/1: (2): $104-113$.

Tobing, E., 2009. Educational bill and the real mess behind the educational system. The Jakarta Post, June 26.

UNESCO.(1998). Statistical Year of Indonesian Education. Paris: UNESCO.

Vira, N. 2002. Teaching English in Cabodian secondary schools: with a special focus on teaching preferences towards the improvement of their professional careers in language teaching. Bull Grad School Education Horishima University. Part II, No.51. pp. 197-206.
Yasin, A., 2001. Tes Kompetensi Komunikatif. http://www.geocities.com/anasyasin/tesk ompkom.html. [April 14 ${ }^{\text {th }} 2008$ ].

Yuwono, G., 2005. English Language Teaching in Decentralised Indonesia: Voices from the less privileged Schools. Available from: [April 14 ${ }^{\text {th }}$ 2008].

Yusuf M. and Sewoyo S., 1997. The Evaluation of ELT at Trisakti University and Its Follow-UP. In Teaching English to University Undergraduates in the Indonesian Contexts: Issues and Development (pp.61-68), ITB Press and University of Leeds, GB.

Zainil. 2005. Motivating the Reluctant Language Learner. Padati-Web Journal. Available from: [September 2006]. Robson, Jocelyn. 2010. "Active 